\title{
Sphingosine 1-Phosphate as a Link between Blood Coagulation and Inflammation
}

\author{
Bernhard Hermann Rauch
}

Institut für Pharmakologie, Abteilung Allgemeine Pharmakologie, Universitätsmedizin Greifswald, Ernst-Moritz-Arndt-Universität, Greifswald, Germany

\section{Key Words}

Sphingosin-1-phosphate - Thrombin • Factor-Xa • Sphingosine kinase $\cdot$ Platelet • Vascular smooth muscle $\cdot$ Monocyte $\cdot$ Atherosclerosis

\begin{abstract}
Sphingosine 1-phosphate (S1P) is a multifunctional signaling lipid generated from sphingosine by sphingosine kinases. S1P formation has been shown in numerous cells in the circulation, including platelets, vascular endothelial and smooth muscle cells and monocytes. S1P also exerts multiple effects on these cells, i.e. cell proliferation and migration, activation of proinflammatory signaling pathways and release of additional inflammatory mediators. Similar activities and targets have also been identified for activated clotting factors such as thrombin or the activated factor-X (FXa), suggesting a possible involvement of S1P in thrombusassociated cellular signaling and thrombin-induced inflammatory reactions. Several levels of S1P-mediated, thrombin /FXa-induced signaling have already been identified: regulation of sphingosine kinase expression and activity, stimulation of S1P release from platelets and other cells and, possibly regulation of S1P-receptors on target cells. This review summarizes the current state of knowledge about S1P as a clotting factor-regulated molecular link between blood coagulation and inflammation. It is concluded that S1P might represent an until now underestimated lipid mediator of inflammatory reactions following activation of the clotting system and, in this context, also involved in the development and progression of atherosclerosis.
\end{abstract}




\section{Introduction}

A blood clot, formed within minutes after vascular injury not only serves to stop acute bleeding but also contains numerous chemical factors, most notably the clotting factors Xa and thrombin, that are necessary for subsequent tissue repair and remodeling [1, 2]. As soon as free tissue factor (TF) becomes exposed after vascular injury, the coagulation cascade is initiated. Binding of activated factor-VII to TF allows for the binding of factor X and its subsequent conversion to FXa. FXa then stimulates thrombin generation and subsequent platelet activation and fibrinogen cleavage, eventually resulting in the formation of a mural thrombus [3,4]. These processes are amplified by a number of positive feedback mechanisms which ultimately result in huge amounts of thrombin, largely generated from the already existing thrombus, which play a pivotal role in post-thrombotic inflammatory and tissue repair reactions $[5,6]$. In this context, it should be noted that the overwhelming portion of thrombus-associated thrombin, more than $95 \%$, is formed after clotting is completed [7]. Consequently, inhibitors of thrombin and/or FXa attenuate inflammatory and proliferative responses in vascular cells in experimental settings [8]. These cellular effects of thrombin and FXa are mediated independently of each other via a family of G-protein coupled receptors, the protease-activated receptors- $1,-2,-3$ and -4 (PAR-1 to PAR-4) $[9,10]$. While thrombin acts via PAR-1, PAR-2 and PAR-4, FXa can initiate signaling through PAR-1 and PAR-2. In addition, PAR-2 is activated by an array of other proteases such as coagulation factor VIIa, trypsin, tissue kallikreins or mast cell tryptase and possibly by other transmembrane serine proteases [11]. PARs are ubiquitously expressed in platelets, white blood cells and cells of the vasculature $[10,12]$. In the vessel wall, PARs stimulate smooth muscle cell proliferation and migration, modify the composition of the extracellular matrix of blood vessels, and mediate proinflammatory responses $[8,9,13,14]$. Because proliferation and migration of smooth muscle cells are considered key events in the development of atherosclerosis and vascular remodeling, these cellular effects of thrombin and FXa may directly contribute to the pathogenesis of vascular diseases such as progression of atherosclerosis and restenosis after vascular injury $[6,15,16]$.

The lysophospholipid sphingosine 1-phosphate (S1P) is a highly active lipid mediator [17]. S1P originates from the ceramide metabolism. Ceramides are generated either de novo from serine and palmitate or are derived from degradation of complex sphingolipids such as glycosphingolipids [18] and sphingomyelin, which represents the mostabundant sphingolipid in human serum and plasma [19]. Ceramide can then be deacetylated by ceramidase to sphingosine, followed by phosphorylation by sphingosine kinases to produce S1P $[18,20$, 21]. The levels of S1P in blood and tissues are tightly controlled. In human plasma, S1P concentrations within a low micromolar range have been reported [22-24]. In tissues, S1P levels are considerably lower and range presumably within low nanomolar concentrations $[25,26]$. The resulting gradient between blood and tissue compartment controls cellular trafficking of immune cells such as monocytes and lymphocytes or migration of stem cells $[18,25-27]$ and is considered to be the key determinant to coordinate S1P signaling in vivo [28]. Pathophysiological events such as acute vascular injury or persistent proinflammatory challenges of the vessel wall during atherosclerosis [5] are characterized by the activation of the coagulation cascade and platelets thereby increasing local S1P concentrations. This may play an important role for directing immune cells to sites of local injury and directly links the coagulation system to S1P-mediated inflammatory responses in vivo.

Although it has been reported that S1P can also be synthesized in the extracellular space [29], it is predominantly produced intracellularly by sphingosine kinase (SPHK) of which two the isoforms SPHK1 and SPHK2 exist [30, 31]. In early studies, S1P has been reported as an intracellular second messenger-like molecule which is crucial for cellular processes such as cell proliferation and mobilization of calcium from internal stores [32, 33]. The majority of studies however have focused on the functions of extracellular S1P. These numerous cellular actions are mediated by a specific family of G-protein-coupled S1P receptors of which five subtypes named $\mathrm{S}_{1} \mathrm{P}_{1-5}$ are known to date $[34,35]$. Extracellular S1P regulates proliferation 
and migration of divers cell types such as vascular cells but also in several tumor types [21] and is a critical regulator of the physiology of the immune and vascular systems, i.e. regulates lymphocyte egress, angiogenesis and platelet maturation and stem cell functions [25, 3638]. In addition, recent studies highlight numerous interactions between blood coagulation and the S1P signaling system [18]. The purpose of this review is to summarize the current knowledge on the function of S1P as downstream mediator and modulator of inflammatory mechanisms in response to an activated blood coagulation system, specifically to thrombinand FXa-mediated signaling.

\section{Clotting factor-induced SPHK1 expression and S1P production in vascular smooth muscle cells}

Thrombin and FXa regulate many genes in vascular smooth muscle cells, including those for inflammatory cytokines and cell proliferation [8-10]. These transcriptional effects on gene regulation and subsequent cellular reactions are partially due to the recruitment of additional signaling systems, i.e. release of growth factors such as fibroblast growth factor-2 [14, 39], transactivation of the epidermal growth factor receptor [40] or activation of matrix-metalloproteinases [13]. This may also involve transcriptional upregulation and expression of receptors which have previously not been associated with smooth muscle cells such as the P2Y $\mathrm{Y}_{12}$ ADP receptor, typically expressed in platelets and the molecular target of thienopyridine-type antiplatelet agents [41]. An interaction between thrombin-induced PAR-1 signaling and the S1P system via enhanced expression of SPHK1 and elevated S1P synthesis has been first been observed in epithelial and in endothelial cells [42]. In addition, the S1P system has been suggested as a downstream component of thrombin signaling also in other cell types. Work from Niessen et al. revealed a critical role of cross-talk between PAR1 and the S1P3 receptor in dendritic cells for the amplification of inflammation during sepsis [43].

Further studies indicate a direct involvement of thrombin in regulating key processes of cellular proinflammatory responses in vascular smooth muscle cells. This involves activation of classical inflammatory transcription factors such as NF- $\kappa \mathrm{B}$ [44] but also immune regulators that have more recently become of interest such as the forkhead-box-0 transcription factor family [45].

In addition to thrombin, FXa can independently activate PAR-1 and PAR-2. Recent work from our laboratory has shown that FXa regulates transcription of SPHK1 and elevates S1P biosynthesis in human vascular smooth muscle cells (Fig. 1A, 1B) [46]. This stimulatory effect, observed in cultured cells, was seen at FXa concentrations (3 to $30 \mathrm{nM}$ ) which have been shown to occur during thrombus formation ex vivo [8]. Expression of SPHK1 by FXa was attenuated by inhibitors of the Rho-associated kinase and of classical PKC isoforms. In addition, FXa caused activation of the small GTPase RhoA in human smooth muscle cells. This is particularly interesting, because small GTPases are known to play key roles in mediating signaling responses of the S1P receptor [47], suggesting a mutual interaction of S1P receptor-initiated signaling and regulation of S1P synthesis. Another aspect of the study was to demonstrate that FX/FXa is present within human carotid artery plaques and co-localizes with SPHK1 expression (Fig. 1C). The presence of active coagulation factors in atherosclerotic tissue has also been shown by others [48]. This observation suggests a close relation between coagulation factor signaling and progression of the athero-thrombotic disease. Consequently, direct oral anticoagulants, like dabigatran and rivaroxaban, may attenuate the development of atherosclerotic lesions, an effect which has been described for mice [5]. Whether possible antiproliferative or antiatherogenic actions of the novel oral coagulation inhibitors involve affecting SPHK1 expression and modulate S1P-mediated signaling in patients, requires further investigations. 


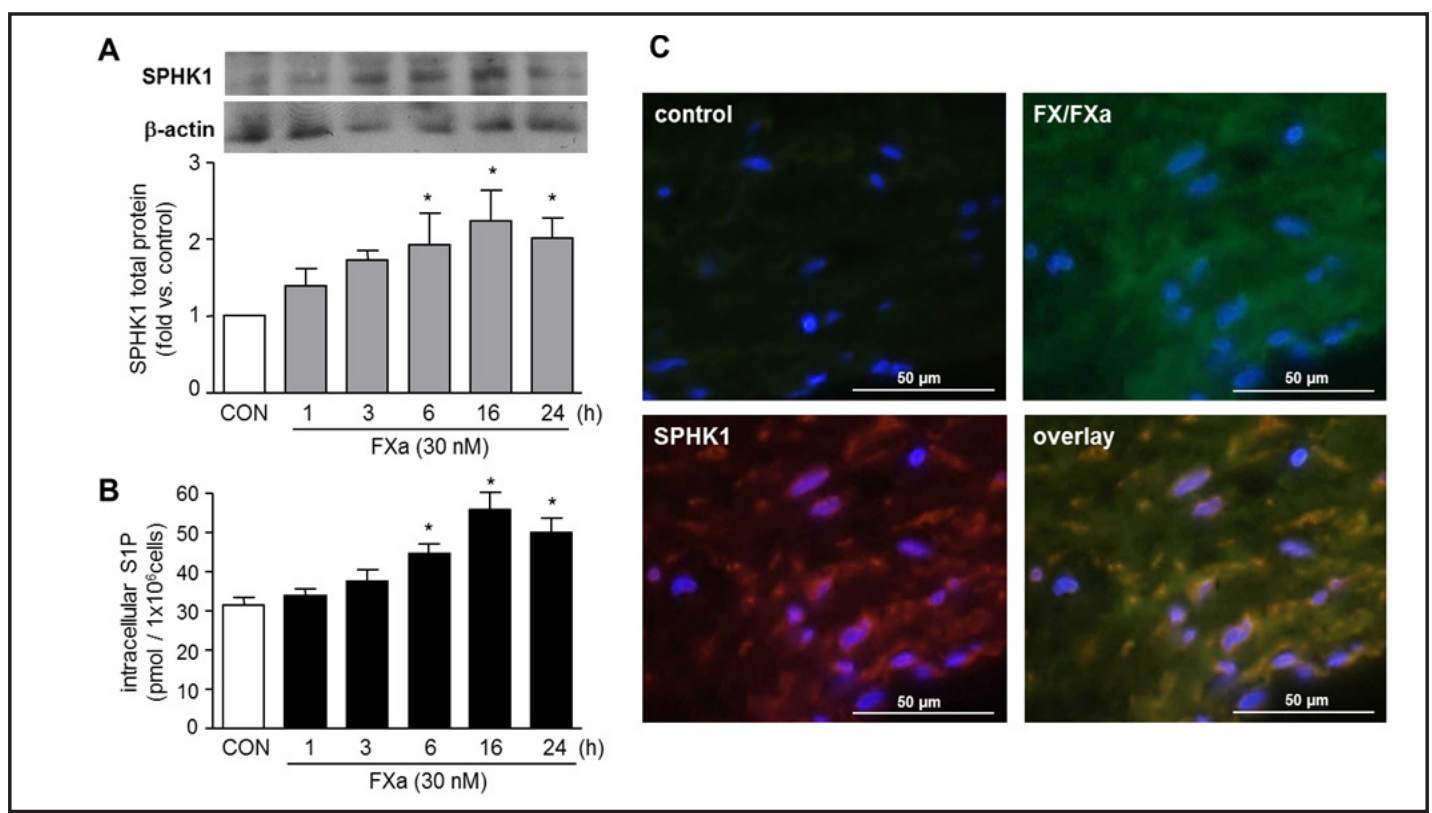

Fig. 1. The activated coagulation factor X (FXa) induces transcriptional regulation of SPHK1 in human vascular smooth muscle cells. (A) Incubation of cells with FXa induced a time-dependent increase in SPHK1 protein expression; $n=7,{ }^{*} p<0.05$. (B) This was accompanied by an increased generation of S1P in these cells; $n=6,{ }^{*} p<0.05$. (C) In human carotid artery plaques, the presence of both FX/FXa (green) and SPHK1 (red) was detected by immunofluorescence staining. Overlay (yellow) indicates a spatial association of both proteins in human atherosclerotic plaques. Modified after Böhm et al. [46].

\section{Clotting factor-induced S1P release from activated platelets}

SPHK is highly active in platelets, which however lack the ability to synthesize sphingosine intracellularly. A recent study from Zang et al. shows that SPHK2 is the predominant isoform in human megakaryocytes and platelets [49]. A rapid uptake of extracellular sphingosine and subsequent phosphorylation into S1P has been proposed as the basic mechanism of S1P synthesis in platelets [50]. In addition to circulating plasma sphingosine, generation of sphingosine at the outer leaflet of the platelet membrane may provide a source for platelet S1P biosynthesis [51]. Platelets store S1P abundantly and secrete it upon activation [22, 50, 52,53 ] because the S1P-degrading enzyme, S1P lyase, is absent in platelets. Interestingly, S1P plasma levels in thrombocytopenic mice were remained largely unchanged [27], suggesting that resting platelets may not substantially contribute to circulating S1P concentrations in plasma. In the human, about $40 \%$ of S1P in platelet-rich plasma appear to be associated with the platelet $[22,54]$ and in patients with thrombocytopenia plasma S1P levels correlated most closely with platelet count [53]. Under conditions of enhanced platelet activation such as arterial thrombus formation, most likely the platelet becomes the predominant local source of S1P.

Platelets release huge amounts of S1P during blood clotting or upon direct activation with agonists of protein kinase C signaling like thrombin $[55,56]$. Data from our group suggest a key role of thromboxane in S1P release from human platelets [22]. After platelet activation with potent agonists such as thrombin, thrombin receptor-activating peptides or with a high collagen concentration, secretion of platelet S1P is induced. This effect was largely prevented after inhibition of thromboxane formation by inhibitors of cyclooxygenase-1, such as aspirin, diclofenac or ibuprofen (Fig. 2 and [22]), suggesting S1P release is mediated via thromboxane. The essential role of thromboxane in thrombin-induced S1P-release 
A

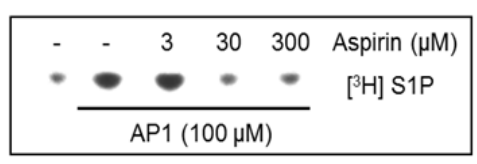

B

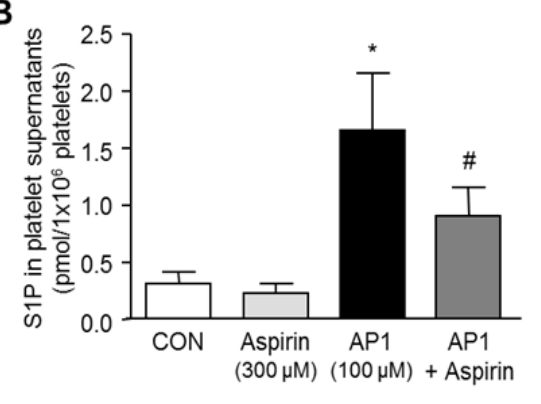

C

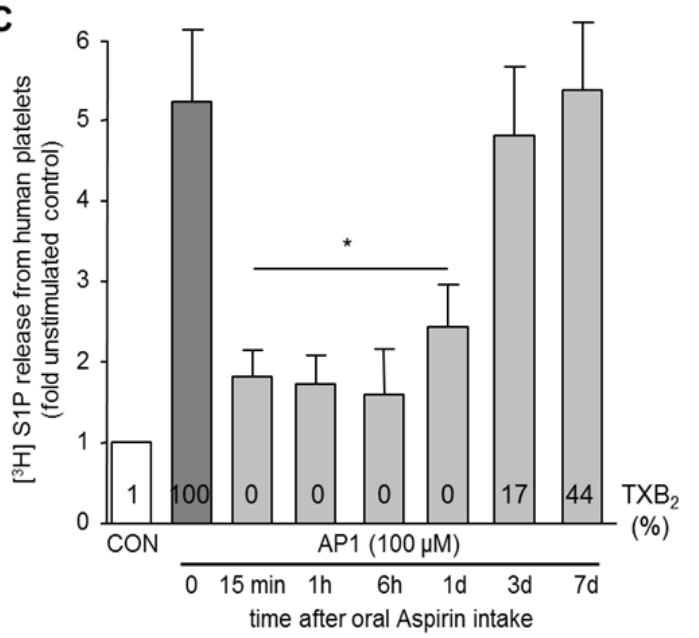

Fig. 2. The release of S1P from activated human platelets is thromboxane-dependent and is inhibited by aspirin. (A) Human platelets were loaded ex vivo with [3H]-labelled sphingosine which is rapidly converted into [3H]S1P. Platelets were pre-incubated with aspirin for 10 minutes, which was then removed by washing prior to activation with the potent platelet agonist for the thrombin receptor PAR-1 (PAR-1-activating peptide, AP1). Lipids were extracted from platelet supernatants and the released [3H]S1P was determined by thin-layer chromatography. (B) Release of endogenous, unlabelled platelet S1P and the effect of aspirin was also determined by HPLC/mass spectrometry; $n=10,{ }^{*} p<0.05$ vs. CON, ${ }^{*} p<0.05$ vs. AP1. (C) Release of $\mathrm{S} 1 \mathrm{P}$, determined ex vivo, was inhibited by oral aspirin (500 $\mathrm{mg}$ single dose). This effect was paralleled by the inhibition of thromboxane synthesis (determined as $\mathrm{TXB}_{2}$ ); $\mathrm{n}=4,{ }^{*} \mathrm{p}<0.05$. Modified after Ulrych et al. [22].

was further documented by its inhibition with a thromboxane receptor antagonist and its absence in platelets from thromboxane receptor knockout mice [22].

Cellular S1P secretion requires active transport across the membrane by adenosinetriphosphate (ATP)-dependent carriers, members of the ATP transporter family. In mast cells or in erythrocytes ABCC1 or ABCA1, respectively, are involved in S1P release [57, 58]. In platelets, transporters exert important functions for translocation and storage of signaling molecules [59]. ABCC4, a member of the C-branch of the ABC transporters, is abundantly expressed in human platelets [60]. The combined use of several $A B C$ transport inhibitors point to a role of ABCC4 for export of platelet S1P [22], however the specific involvement and a possible pharmacological modulation of this transport candidate, requires further evaluation.

Further studies addressed the question, whether aspirin is effective to inhibit S1P secretion in human platelets in vivo. Oral aspirin either at $500 \mathrm{mg}$ single dose or at $100 \mathrm{mg}$ over three days attenuated agonist-induced S1P release from human platelets determined ex vivo. This was accompanied by inhibition of thromboxane synthesis (Fig. 2C and [22]), indicating that aspirin was efficient to affect S1P release also after oral intake at antiplatelet doses. Recent data from Knapp et al. show a dose-dependent effect of aspirin with higher doses reducing plasma S1P, but no impact on basal platelet S1P [61]. This is in agreement with the observation that aspirin does not affect platelet de novo S1P synthesis [22]. Under conditions of elevated thrombin formation and platelet activation however, aspirin may attenuate platelet S1P release. A potential effect of aspirin on platelet S1P was investigated in patients with acute myocardial infarction. Here, application of aspirin (500 mg i.v.) attenuated S1P release and resulted in an containment of S1P within the platelet [54]. Interestingly, in certain clinical conditions, acute coronary syndromes, plasma S1P level decrease substantially $[23,24,54,62]$. This may be explained by compartmentalization of plasma S1P to red blood cells or to certain carrier molecules such as HDL [24, 62]. 


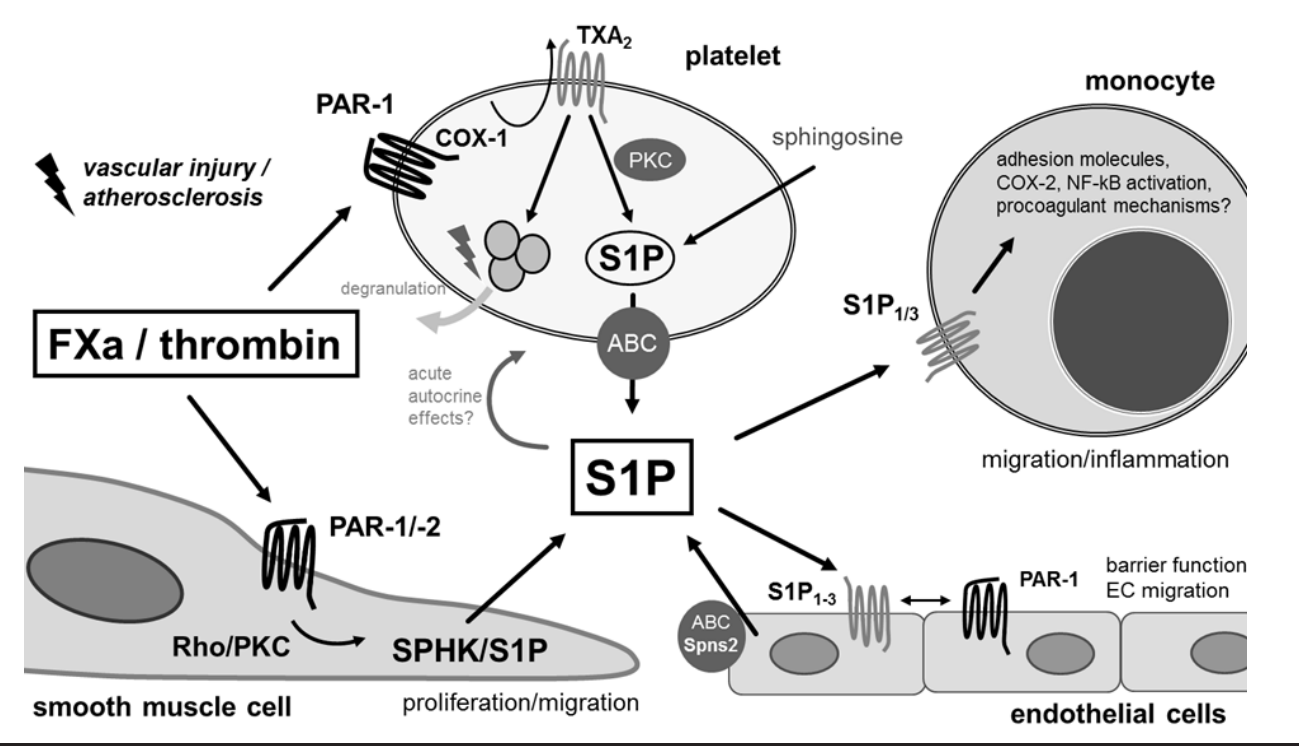

Fig. 3. The blood coagulation factors thrombin and FXa interact with local S1P availability and its cellular effects at multiple levels. In vascular smooth muscle cells, S1P synthesis and release is enhanced in response to activation of the receptors for thrombin and FXa (PAR-1 and PAR-2) due to transcriptional upregulation of SPHK-1. In human platelets, secretion of S1P is stimulated by potent agonists such as thrombin. This is mediated by thromboxane and involves an ABC-dependent transport mechanism. In addition, endothelial cells release S1P via Spns2. S1P regulates endothelial barrier function and cell migration and plays a key role in angiogenesis and presumably wound healing. These processes may also involve interactions between the receptors for S1P and thrombin. In monocytes, S1P enhances cellular activity and evokes proinflammatory responses, which may modulate their response to injury and during thrombosis. Abbreviations used: ABC, adenosine triphosphate-binding cassette transporter; COX-1, cyclooxygenase-1; FXa, activated coagulation factor X; NF- $\kappa B$, nuclear factor- $\kappa B$; PAR-1/-2, protease-activated receptor-1/-2; PKC, protein kinase C; Rho, Ras-homologue GTPase family member; S1P, sphingosine 1-phosphate; $\mathrm{S} 1 \mathrm{P}_{1-3}$, S1P receptors 1 to 3; Spns2, spinster homolog 2; $\mathrm{TXA}_{2}$, thromboxane $\mathrm{A}_{2}$.

The (patho)physiological functions of platelet-derived S1P are still incompletely understood. S1P has been implicated in the initiation phase of platelet aggregation in some [63], but not all studies [22,64]. While these varying results may in part reflect different experimental designs, S1P does not appear to function as a direct platelet agonist. However, platelets do express S1P receptors and recent studies in mice indicate a role for S1P in thrombopoiesis [37].

\section{Coagulation factor effects and S1P functions in endothelial cells}

Blood-borne S1P is derived from several sources. Endothelial cells synthesize and secrete large amounts of S1P and contribute substantially to generating the high level present in the blood $[28,29]$. Recent studies have revealed a critical role of the S1P transporter spinster homolog 2 (Spns2) for endothelial S1P release and for lymphocyte trafficking $[65,66]$. This may however be of particularly importance for the secretion of lymph but not plasma S1P [67]. S1P regulates a wide array of biological functions in endothelial cells. Key functions in the endothelium involve stimulation of cell migration, regulation of proinflammatory responses [68,69] and control of its barrier function [34, 70-72]. It is also well established that thrombin is an important regulator of vascular inflammation [73]. This includes induction of endothelial cell contraction and disruption of endothelial barrier integrity [74], which is mediated via activation of the thrombin receptor PAR-1 [72]. More recently, it was found that S1P signaling can counteract this detrimental effect of thrombin. This involves 
generation of activated protein C [72] and may thus be attributed to a partial inhibition of thrombin activity as well as activation of SPHK1 and consecutive release of S1P [75]. Thus, thrombin appears to induce S1P signaling in the endothelium to counteract its own action to induce vascular leakage.

Another level of interaction between coagulation factor and S1P signaling involves cross-talk of the respective receptor systems [43]. In particular systemic diseases such as sepsis, signaling through PAR-1 exerts opposing functions. This has been attributed to either promoting dendritic cell-dependent coagulation and inflammation or reducing sepsis lethality due to protein $C$ activation and involves regulation of the vascular S1P (S1P1/S1P3) receptor balance [76].

Not only PAR signaling but also S1P actions in endothelial cells appear to involve opposing mechanisms. While S1P on the one hand enhances barrier integrity to counteract thrombin effects and restore vascular homeostasis after injury, one other hand it synergizes with thrombin in upregulating the expression of TF in endothelial cells [77]. Thereby, S1P may enhance generation of thrombin under proinflammatory conditions such as atherosclerosis. In this context, a recent study from Campos et al. is of interest, which showed that the functional S1P receptor antagonist fingolimod [78] reduces infarct size and enhances blood-brain barrier integrity in rodent models of stroke [79]. To determine whether this observation, besides an effect on barrier function, involves direct thrombotic or antithrombotic mechanisms of S1P signaling requires further investigations.

\section{Interactions between coagulation factors and S1P in monocytes}

After activation of blood clotting and thrombus formation, immigration of inflammatory cells occurs, allowing for activation of the cellular immune system. Monocytes, as representatives of the innate immune system, play a major role in the initiation, propagation, and progression of atherosclerosis from a stable to an unstable state [80]. Thrombin induces a number of cellular effects in monocytes, i.e. enhances inflammatory responses such as release of IL-6 [81] and stimulates cell migration [82]. Monocytes express both thrombin and $\mathrm{S} 1 \mathrm{P}$ receptors $[83,84]$ and both receptor families have been implicated in the development of atherosclerosis $[5,80]$, in addition to their known interaction at the molecular level in other cell types [43]. Thus, it is likely that direct interactions may also link PAR and S1P signaling in monocytes. Preliminary data from our group indicate that S1P enhances thrombin-induced migration of human monocytes via transcriptional upregulation of PAR-4 [85]. This may enhance responsiveness and monocyte activity in response to local thrombin formation at sites of injury.

Another striking observation was the finding that sphingosine can inhibit monocyte tissue factor-initiated coagulation by altering factorVII binding [86]. The underlying molecular mechanism might involve direct allosteric inhibition of tissue factor activity or modulation of procoagulant cell membrane surfaces. However, the sphingosine concentrations required to see this effect were in the micromolar range [86] and it is unclear whether endogenous sphingosine or its conversion from locally release S1P could reach these high levels.

An indirect interaction which couples coagulation factor and S1P signaling during thrombus formation is the release of S1P from activated platelets (see above). Plateletderived S1P may modulate the biological responses of adjacent cells, including monocytes. Thus, platelets-derived S1P may - in concert with other chemokines - serve as a paracrine mediator to regulate monocyte migration and attract these cells to sites of vascular injury $[22,87]$.

\section{Conclusions and future perspectives}

Signaling mechanisms of blood coagulation factors as well as the ubiquitous immunomodulatory actions of S1P represent essential physiological systems, which are 
intimately linked a several levels (see scheme in Fig. 3). Pathophysiological functioning of both systems are key elements of numerous diseases such as thrombosis, inflammation, atherosclerosis and cancer.

Regulation of SPHK expression and thus the control of intracellular S1P synthesis by thrombin and FXa are involved in proliferative responses and chemotaxis in vascular endothelial and smooth muscle cells (Fig. 3). This mechanism may thereby contribute to athero-thrombotic disease progression. Similar mechanisms may apply to other diseases strongly associated with inflammation and thrombosis, i.e. certain cancer types. Many cancer cells exhibit prothrombotic properties such as elevated TF and PAR expression $[88,89]$ and S1P has been identified as an important regulator in the pathophysiology of cancer [21,36].

Platelet activation especially during arterial thrombus formation may be the major source of local S1P release after vascular injury. The mechanism of S1P secretion from activated human platelet, i.e. after exposure to thrombin, requires generation of thromboxane, involves ABC-mediated transport and is mediated via the thromboxane receptor. Future antiinflammatory strategies could be focused on this unique release mechanism to modulate the pro-inflammatory and athero-thrombotic actions of activated platelets. Interestingly, the S1P receptor modulator fingolimod has recently been shown to ameliorate the severity of acute ischemic stroke in mice by reducing thrombo-inflammation rather than by direct neuroprotection [90]. Taken together, pharmacological targeting of the numerous mutual interactions of blood coagulation factors with the S1P system may offer exciting new perspectives for improved treatment of inflammatory diseases, including athero-thrombosis.

\section{Disclosure Statement}

No conflict of interest has been declared.

\section{Acknowledgments}

This work was supported by grants from the Deutsche Forschungsgemeinschaft to B.H.R (DFG RA1714/1-1/1-2).

\section{References}

1 Nurden AT: Platelets, inflammation and tissue regeneration. Thromb Haemost 2011;105 Suppl 1:S13-S33.

-2 Levi M, van der Poll T, Schultz M: Infection and inflammation as risk factors for thrombosis and atherosclerosis. Semin Thromb Hemost 2012;38:506-514.

3 Krupiczojc MA, Scotton CJ, Chambers RC: Coagulation signalling following tissue injury: focus on the role of factor Xa. Int J Biochem Cell Biol 2008;40:1228-1237.

$\checkmark 4$ Owens AP, 3rd, Mackman N: Role of tissue factor in atherothrombosis. Curr Atheroscler Rep 2012;14:394401.

5 Kalz J, ten Cate H, Spronk HM: Thrombin generation and atherosclerosis. J Thromb Thrombolysis 2014;37:45-55.

6 Borensztajn K, Peppelenbosch MP, Spek CA: Factor Xa: at the crossroads between coagulation and signaling in physiology and disease. Trends Mol Med 2008;14:429-440.

7 Brummel KE, Paradis SG, Butenas S, Mann KG: Thrombin functions during tissue factor-induced blood coagulation. Blood 2002;100:148-152.

8 Rosenkranz AC, Schrör K, Rauch BH: Direct inhibitors of thrombin and factor Xa attenuate clot-induced mitogenesis and inflammatory gene expression in human vascular smooth muscle cells. Thromb Haemost 2011;106:561-562. 


\begin{tabular}{|c|c|c|}
\hline Cellular Physiology & Cell Physiol Biochem 2014;34:185-196 & \\
\hline and Biochemistry & $\begin{array}{l}\text { DOI: 10.1159/000362994 } \\
\text { Publishea online: June 16, } 2014\end{array}$ & $\begin{array}{l}\text { O } 2014 \text { S. Karger AG, Basel } \\
\text { www.karger.com/cpb }\end{array}$ \\
\hline
\end{tabular}

9 Schrör K, Bretschneider E, Fischer K, Fischer JW, Pape R, Rauch BH, Rosenkranz AC, Weber AA: Thrombin receptors in vascular smooth muscle cells - function and regulation by vasodilatory prostaglandins. Thromb Haemost 2010;103:884-890.

10 Ma L, Dorling A: The roles of thrombin and protease-activated receptors in inflammation. Semin Immunopathol 2012;34:63-72.

11 Rothmeier AS, Ruf W: Protease-activated receptor 2 signaling in inflammation. Semin Immunopathol 2012;34:133-149.

12 Coughlin SR: Protease-activated receptors in hemostasis, thrombosis and vascular biology. J Thromb Haemost 2005;3:1800-1814.

-13 Rauch BH, Bretschneider E, Braun M, Schrör K: Factor Xa releases matrix metalloproteinase-2 (MMP-2) from human vascular smooth muscle cells and stimulates the conversion of pro-MMP-2 to MMP-2: role of MMP-2 in factor Xa-induced DNA synthesis and matrix invasion. Circ Res 2002;90:1122-1127.

14 Rauch BH, Millette E, Kenagy RD, Daum G, Clowes AW: Thrombin- and factor Xa-induced DNA synthesis is mediated by transactivation of fibroblast growth factor receptor-1 in human vascular smooth muscle cells. Circ Res 2004;94:340-345.

15 Borensztajn K, Spek CA: Blood coagulation factor Xa as an emerging drug target. Expert Opin Ther Targets 2011;15:341-349.

16 Shah R: Protease-activated receptors in cardiovascular health and diseases. Am Heart J2009;157:253-262.

17 Maceyka M, Harikumar KB, Milstien S, Spiegel S: Sphingosine-1-phosphate signaling and its role in disease. Trends Cell Biol 2012;22:50-60.

18 Obinata H, Hla T: Sphingosine 1-phosphate in coagulation and inflammation. Semin Immunopathol 2012;34:73-91.

19 Hammad SM, Pierce JS, Soodavar F, Smith KJ, Al Gadban MM, Rembiesa B, Klein RL, Hannun YA, Bielawski J, Bielawska A: Blood sphingolipidomics in healthy humans: impact of sample collection methodology. J Lipid Res 2010;51:3074-3087.

20 Chalfant CE, Spiegel S: Sphingosine 1-phosphate and ceramide 1-phosphate: expanding roles in cell signaling. J Cell Sci 2005;118:4605-4612.

21 Kunkel GT, Maceyka M, Milstien S, Spiegel S: Targeting the sphingosine-1-phosphate axis in cancer, inflammation and beyond. Nat Rev Drug Discov 2013;12:688-702.

22 Ulrych T, Böhm A, Polzin A, Daum G, Nusing RM, Geisslinger G, Hohlfeld T, Schrör K, Rauch BH: Release of sphingosine-1-phosphate from human platelets is dependent on thromboxane formation. J Thromb Haemost 2011;9:790-798.

23 Knapp M, Baranowski M, Czarnowski D, Lisowska A, Zabielski P, Gorski J, Musial W: Plasma sphingosine-1phosphate concentration is reduced in patients with myocardial infarction. Med Sci Monit 2009;15:CR490CR493.

-24 Sattler KJ, Elbasan S, Keul P, Elter-Schulz M, Bode C, Graler MH, Brocker-Preuss M, Budde T, Erbel R, Heusch G, Levkau B: Sphingosine 1-phosphate levels in plasma and HDL are altered in coronary artery disease. Basic Res Cardiol 2010;105:821-832.

-25 Cyster JG, Schwab SR: Sphingosine-1-phosphate and lymphocyte egress from lymphoid organs. Annu Rev Immunol 2012;30:69-94.

26 Green JA, Suzuki K, Cho B, Willison LD, Palmer D, Allen CD, Schmidt TH, Xu Y, Proia RL, Coughlin SR, Cyster JG: The sphingosine 1-phosphate receptor S1P(2) maintains the homeostasis of germinal center B cells and promotes niche confinement. Nat Immunol 2011;12:672-680.

27 Venkataraman K, Lee YM, Michaud J, Thangada S, Ai Y, Bonkovsky HL, Parikh NS, Habrukowich C, Hla T: Vascular endothelium as a contributor of plasma sphingosine 1-phosphate. Circ Res 2008;102:669-676.

28 Olivera A, Allende ML, Proia RL: Shaping the landscape: metabolic regulation of S1P gradients. Biochim Biophys Acta 2013;1831:193-202.

29 Venkataraman K, Thangada S, Michaud J, Oo ML, Ai Y, Lee YM, Wu M, Parikh NS, Khan F, Proia RL, Hla T: Extracellular export of sphingosine kinase-1a contributes to the vascular S1P gradient. Biochem J 2006;397:461-471.

-30 Melendez AJ, Carlos-Dias E, Gosink M, Allen JM, Takacs L: Human sphingosine kinase: molecular cloning, functional characterization and tissue distribution. Gene 2000;251:19-26. 


\begin{tabular}{|c|c|c|}
\hline Cellular Physiology & Cell Physiol Biochem 2014;34:185-196 & \\
\hline and Biochemistry & $\begin{array}{l}\text { DOI: 10.1159/000362994 } \\
\text { Publisned onine: June 16, } 2014\end{array}$ & $\begin{array}{l}\text { O } 2014 \text { S. Karger AG, Basel } \\
\text { www.karger.com/cpb }\end{array}$ \\
\hline
\end{tabular}

-31 Liu H, Sugiura M, Nava VE, Edsall LC, Kono K, Poulton S, Milstien S, Kohama T, Spiegel S: Molecular cloning and functional characterization of a novel mammalian sphingosine kinase type 2 isoform. J Biol Chem 2000;275:19513-19520.

32 Mattie M, Brooker G, Spiegel S: Sphingosine-1-phosphate, a putative second messenger, mobilizes calcium from internal stores via an inositol trisphosphate-independent pathway. J Biol Chem 1994;269:3181-3188.

-33 Zhang H, Desai NN, Olivera A, Seki T, Brooker G, Spiegel S: Sphingosine-1-phosphate, a novel lipid, involved in cellular proliferation. J Cell Biol 1991;114:155-167.

34 Blaho VA, Hla T: An update on the biology of sphingosine 1-phosphate receptors. J Lipid Res 2014

-35 Chun J, Hla T, Lynch KR, Spiegel S, Moolenaar WH: International Union of Basic and Clinical Pharmacology. LXXVIII. Lysophospholipid receptor nomenclature. Pharmacol Rev 2010;62:579-587.

-36 Takabe K, Spiegel S: Export of Sphingosine-1-Phosphate and Cancer Progression. J Lipid Res 2014; in press.

-37 Zhang L, Orban M, Lorenz M, Barocke V, Braun D, Urtz N, Schulz C, von Bruhl ML, Tirniceriu A, Gaertner F, Proia RL, Graf T, Bolz SS, Montanez E, Prinz M, Muller A, von Baumgarten L, Billich A, Sixt M, Fassler R, von Andrian UH, Junt T, Massberg S: A novel role of sphingosine 1-phosphate receptor S1pr1 in mouse thrombopoiesis. J Exp Med 2012;209:2165-2181.

38 Ratajczak MZ, Suszynska M, Borkowska S, Ratajczak J, Schneider G: The role of sphingosine-1 phosphate and ceramide- 1 phosphate in trafficking of normal stem cells and cancer cells. Expert Opin Ther Targets 2014;18:95-107.

-39 Rauch BH, Scholz GA, Baumgartel-Allekotte D, Censarek P, Fischer JW, Weber AA, Schrör K: Cholesterol enhances thrombin-induced release of fibroblast growth factor-2 in human vascular smooth muscle cells. Arterioscler Thromb Vasc Biol 2007;27:e20-e25.

40 Kalmes A, Daum G, Clowes AW: EGFR transactivation in the regulation of SMC function. Ann N Y Acad Sci 2001;947:42-55.

-41 Rauch BH, Rosenkranz AC, Ermler S, Böhm A, Driessen J, Fischer JW, Sugidachi A, Jakubowski JA, Schrör K: Regulation of functionally active P2Y12 ADP receptors by thrombin in human smooth muscle cells and the presence of P2Y12 in carotid artery lesions. Arterioscler Thromb Vasc Biol 2010;30:2434-2442.

$\checkmark 42$ Billich A, Urtz N, Reuschel R, Baumruker T: Sphingosine kinase 1 is essential for proteinase-activated receptor-1 signalling in epithelial and endothelial cells. Int J Biochem Cell Biol 2009;41:1547-1555.

43 Niessen F, Schaffner F, Furlan-Freguia C, Pawlinski R, Bhattacharjee G, Chun J, Derian CK, Andrade-Gordon P, Rosen H, Ruf W: Dendritic cell PAR1-S1P3 signalling couples coagulation and inflammation. Nature 2008;452:654-658.

44 Bretschneider E, Wittpoth M, Glusa E, Schrör K: The role of NF kappa B in thrombin-induced mitogenesis of vascular smooth muscle cells. Thromb Haemost 1997:P1414-P1414.

45 Mahajan SG, Fender AC, Meyer-Kirchrath J, Kurt M, Barth M, Sagban TA, Fischer JW, Schrör K, Hohlfeld T, Rauch BH: A novel function of FoxO transcription factors in thrombin-stimulated vascular smooth muscle cell proliferation. Thromb Haemost 2012;108:148-158.

-46 Böhm A, Flößer A, Ermler S, Fender AC, Luth A, Kleuser B, Schrör K, Rauch BH: Factor-Xa-induced mitogenesis and migration require sphingosine kinase activity and S1P formation in human vascular smooth muscle cells. Cardiovasc Res 2013;99:505-513.

-47 Xiang SY, Dusaban SS, Brown JH: Lysophospholipid receptor activation of RhoA and lipid signaling pathways. Biochim Biophys Acta 2013;1831:213-222.

48 Borissoff JI, Heeneman S, Kilinc E, Kassak P, Van Oerle R, Winckers K, Govers-Riemslag JW, Hamulyak K, Hackeng TM, Daemen MJ, ten Cate H, Spronk HM: Early atherosclerosis exhibits an enhanced procoagulant state. Circulation 2010;122:821-830.

49 Zhang L, Urtz N, Gaertner F, Legate KR, Petzold T, Lorenz M, Mazharian A, Watson SP, Massberg S: Sphingosine kinase 2 (Sphk2) regulates platelet biogenesis by providing intracellular sphingosine 1-phosphate (S1P). Blood 2013;122:791-802.

50 Tani M, Sano T, Ito M, Igarashi Y: Mechanisms of sphingosine and sphingosine 1-phosphate generation in human platelets. J Lipid Res 2005;46:2458-2467.

51 Tani M, Ito M, Igarashi Y: Ceramide/sphingosine/sphingosine 1-phosphate metabolism on the cell surface and in the extracellular space. Cell Signal 2007;19:229-237.

52 Yatomi Y, Igarashi Y, Yang L, Hisano N, Qi R, Asazuma N, Satoh K, Ozaki Y, Kume S: Sphingosine 1-phosphate, a bioactive sphingolipid abundantly stored in platelets, is a normal constituent of human plasma and serum. J Biochem 1997;121:969-973. 


\begin{tabular}{|c|c|c|}
\hline Cellular Physiology & Cell Physiol Biochem 2014;34:185-196 & \\
\hline and Biochemistry & $\begin{array}{l}\text { DOI: 10.1159/000362994 } \\
\text { Published online: June 16, } 2014\end{array}$ & $\begin{array}{l}\text { O } 2014 \text { S. Karger AG, Basel } \\
\text { www.karger.com/cpb }\end{array}$ \\
\hline
\end{tabular}

53 Ono Y, Kurano M, Ohkawa R, Yokota H, Igarashi K, Aoki J, Tozuka M, Yatomi Y: Sphingosine 1-phosphate release from platelets during clot formation: close correlation between platelet count and serum sphingosine 1-phosphate concentration. Lipids Health Dis 2013;12:20.

54 Polzin A, Rassaf T, Böhm A, Luth A, Kleuser B, Zeus T, Kelm M, Kroemer HK, Schrör K, Rauch BH: Aspirin inhibits release of platelet-derived sphingosine-1-phosphate in acute myocardial infarction. Int J Cardiol 2013;170:e23-e24.

55 Yatomi Y, Ohmori T, Rile G, Kazama F, Okamoto H, Sano T, Satoh K, Kume S, Tigyi G, Igarashi Y, Ozaki Y: Sphingosine 1-phosphate as a major bioactive lysophospholipid that is released from platelets and interacts with endothelial cells. Blood 2000;96:3431-3438.

56 English D, Welch Z, Kovala AT, Harvey K, Volpert OV, Brindley DN, Garcia JG: Sphingosine 1-phosphate released from platelets during clotting accounts for the potent endothelial cell chemotactic activity of blood serum and provides a novel link between hemostasis and angiogenesis. Faseb J 2000;14:2255-2265.

57 Kobayashi N, Kobayashi N, Yamaguchi A, Nishi T: Characterization of the ATP-dependent sphingosine 1-phosphate transporter in rat erythrocytes. J Biol Chem 2009;284:21192-21200.

58 Mitra P, Oskeritzian CA, Payne SG, Beaven MA, Milstien S, Spiegel S: Role of ABCC1 in export of sphingosine1-phosphate from mast cells. Proc Natl Acad Sci U S A 2006;103:16394-16399.

59 Jedlitschky G, Greinacher A, Kroemer HK: Transporters in human platelets: physiologic function and impact for pharmacotherapy. Blood 2012;119:3394-3402.

60 Jedlitschky G, Tirschmann K, Lubenow LE, Nieuwenhuis HK, Akkerman JW, Greinacher A, Kroemer HK: The nucleotide transporter MRP4 (ABCC4) is highly expressed in human platelets and present in dense granules, indicating a role in mediator storage. Blood 2004;104:3603-3610.

61 Knapp M, Lisowska A, Knapp P, Baranowski M: Dose-dependent effect of aspirin on the level of sphingolipids in human blood. Adv Med Sci 2013;58:274-281.

-62 Knapp M, Lisowska A, Zabielski P, Musial W, Baranowski M: Sustained decrease in plasma sphingosine-1phosphate concentration and its accumulation in blood cells in acute myocardial infarction. Prostaglandins Other Lipid Mediat 2013;106:53-61.

63 Yatomi Y, Ruan F, Hakomori S, Igarashi Y: Sphingosine-1-phosphate: a platelet-activating sphingolipid released from agonist-stimulated human platelets. Blood 1995;86:193-202.

64 Nugent D, Xu Y: Sphingosine-1-phosphate: characterization of its inhibition of platelet aggregation. Platelets 2000;11:226-232.

65 Hisano Y, Kobayashi N, Yamaguchi A, Nishi T: Mouse SPNS2 functions as a sphingosine-1-phosphate transporter in vascular endothelial cells. PLoS One 2012;7:e38941.

66 Fukuhara S, Simmons S, Kawamura S, Inoue A, Orba Y, Tokudome T, Sunden Y, Arai Y, Moriwaki K, Ishida J, Uemura A, Kiyonari H, Abe T, Fukamizu A, Hirashima M, Sawa H, Aoki J, Ishii M, Mochizuki N: The sphingosine-1-phosphate transporter Spns2 expressed on endothelial cells regulates lymphocyte trafficking in mice. J Clin Invest 2012;122:1416-1426.

-67 Mendoza A, Breart B, Ramos-Perez WD, Pitt LA, Gobert M, Sunkara M, Lafaille JJ, Morris AJ, Schwab SR: The transporter Spns2 is required for secretion of lymph but not plasma sphingosine-1-phosphate. Cell Rep 2012;2:1104-1110.

-68 Zhang W, An J, Jawadi H, Siow DL, Lee JF, Zhao J, Gartung A, Maddipati KR, Honn KV, Wattenberg BW, Lee MJ: Sphingosine-1-phosphate receptor-2 mediated NFkappaB activation contributes to tumor necrosis factor-alpha induced VCAM-1 and ICAM-1 expression in endothelial cells. Prostaglandins Other Lipid Mediat 2013;106:62-71.

69 Zhang G, Yang L, Kim GS, Ryan K, Lu S, O’Donnell RK, Spokes K, Shapiro N, Aird WC, Kluk MJ, Yano K, Sanchez T: Critical role of sphingosine-1-phosphate receptor 2 (S1PR2) in acute vascular inflammation. Blood 2013;122:443-455.

-70 McVerry BJ, Garcia JG: Endothelial cell barrier regulation by sphingosine 1-phosphate. J Cell Biochem 2004;92:1075-1085.

71 Siess W: Athero- and thrombogenic actions of lysophosphatidic acid and sphingosine-1-phosphate. Biochim Biophys Acta 2002;1582:204-215.

72 Feistritzer C, Riewald M: Endothelial barrier protection by activated protein C through PAR1-dependent sphingosine 1-phosphate receptor-1 crossactivation. Blood 2005;105:3178-3184.

73 Popovic M, Smiljanic K, Dobutovic B, Syrovets T, Simmet T, Isenovic ER: Thrombin and vascular inflammation. Mol Cell Biochem 2012;359:301-313. 


\begin{tabular}{|c|c|c|}
\hline Cellular Physiology & Cell Physiol Biochem 2014;34:185-196 & \\
\hline and Biochemistry & $\begin{array}{l}\text { DOI: 10.1159/000362994 } \\
\text { Published online: June 16, } 2014\end{array}$ & $\begin{array}{l}\text { O } 2014 \text { S. Karger AG, Basel } \\
\text { www.karger.com/cpb }\end{array}$ \\
\hline
\end{tabular}

74 Garcia JG, Verin AD, Schaphorst KL: Regulation of thrombin-mediated endothelial cell contraction and permeability. Semin Thromb Hemost 1996;22:309-315.

75 Tauseef M, Kini V, Knezevic N, Brannan M, Ramchandaran R, Fyrst H, Saba J, Vogel SM, Malik AB, Mehta D: Activation of sphingosine kinase-1 reverses the increase in lung vascular permeability through sphingosine-1-phosphate receptor signaling in endothelial cells. Circ Res 2008;103:1164-1172.

-76 Niessen F, Furlan-Freguia C, Fernandez JA, Mosnier LO, Castellino FJ, Weiler H, Rosen H, Griffin JH, Ruf W: Endogenous EPCR/aPC-PAR1 signaling prevents inflammation-induced vascular leakage and lethality. Blood 2009;113:2859-2866.

77 Takeya H, Gabazza EC, Aoki S, Ueno H, Suzuki K: Synergistic effect of sphingosine 1-phosphate on thrombin-induced tissue factor expression in endothelial cells. Blood 2003;102:1693-1700.

-78 Chiba K, Adachi K: Discovery of fingolimod, the sphingosine 1-phosphate receptor modulator and its application for the therapy of multiple sclerosis. Future Med Chem 2012;4:771-781.

-79 Campos F, Qin T, Castillo J, Seo JH, Arai K, Lo EH, Waeber C: Fingolimod reduces hemorrhagic transformation associated with delayed tissue plasminogen activator treatment in a mouse thromboembolic model. Stroke 2013;44:505-511.

80 Ghattas A, Griffiths HR, Devitt A, Lip GY, Shantsila E: Monocytes in coronary artery disease and atherosclerosis: where are we now? J Am Coll Cardiol 2013;62:1541-1551.

81 Domsalla A, Melzig MF: Enhancement of protease-induced IL-6 release in monocytic U-937 cells by phorbol-12-myristate-13-acetate. Inflamm Res 2012;61:1125-1129.

-82 Gadepalli R, Kotla S, Heckle MR, Verma SK, Singh NK, Rao GN: Novel role for p21-activated kinase 2 in thrombin-induced monocyte migration. J Biol Chem 2013;288:30815-30831.

83 Shpacovitch V, Feld M, Hollenberg MD, Luger TA, Steinhoff M: Role of protease-activated receptors in inflammatory responses, innate and adaptive immunity. J Leukoc Biol 2008;83:1309-1322.

84 Keul P, Tolle M, Lucke S, von Wnuck Lipinski K, Heusch G, Schuchardt M, van der Giet M, Levkau B: The sphingosine-1-phosphate analogue FTY720 reduces atherosclerosis in apolipoprotein E-deficient mice. Arterioscler Thromb Vasc Biol 2007;27:607-613.

85 Böhm A, Sostmann B, Rauch BH: The bioactive lipid sphingosine-1-phosphate enhances thrombin-induced migration of human monocytes via transcriptional regulation of the protease-activated receptor-4. Naunyn Schmiedebergs Arch Pharmacol 2013;386:S11-S12.

86 Conkling PR, Patton KL, Hannun YA, Greenberg CS, Weinberg JB: Sphingosine inhibits monocyte tissue factor-initiated coagulation by altering factor VII binding. J Biol Chem 1989;264:18440-18444.

87 Gude DR, Alvarez SE, Paugh SW, Mitra P, Yu J, Griffiths R, Barbour SE, Milstien S, Spiegel S: Apoptosis induces expression of sphingosine kinase 1 to release sphingosine-1-phosphate as a "come-and-get-me" signal. Faseb J 2008;22:2629-2638.

-88 Young A, Chapman O, Connor C, Poole C, Rose P, Kakkar AK: Thrombosis and cancer. Nat Rev Clin Oncol 2012;9:437-449.

89 Franchini M, Mannucci PM: Thrombin and cancer: from molecular basis to therapeutic implications. Semin Thromb Hemost 2012;38:95-101.

-90 Kraft P, Gob E, Schuhmann MK, Gobel K, Deppermann C, Thielmann I, Herrmann AM, Lorenz K, Brede M, Stoll G, Meuth SG, Nieswandt B, Pfeilschifter W, Kleinschnitz C: FTY720 ameliorates acute ischemic stroke in mice by reducing thrombo-inflammation but not by direct neuroprotection. Stroke 2013;44:3202-3210. 